\title{
Biochar Hydrological Characteristics in Related to Branch Wood Properties
}

\author{
Nurul Iman Suansa, ${ }^{\mathrm{a}, \mathrm{b}, *}$ Hamad A. Al-Mefarrej, ${ }^{\mathrm{a}}$ and Thobayet Safar Alshahrani ${ }^{\mathrm{a}}$ \\ Branch wood possesses unique properties that may affect biochar \\ characteristics. Despite the abundance of broad studies on biochar, the \\ correlation between feedstock properties and biochar hydrological \\ characteristics has yet to be elucidated. Therefore, in this work the tree \\ branch wood properties of three feedstocks (Acacia gerrardii Benth., \\ Tamarix aphylla (L.) H. Karst., and Eucalyptus camaldulensis Dehn.) were \\ investigated and compared with the characteristics of biochar produced by \\ pyrolysis at $300^{\circ} \mathrm{C}, 400{ }^{\circ} \mathrm{C}$, and $500^{\circ} \mathrm{C}$. It was found that a higher lumen \\ fraction resulted in a more porous structure, thus increasing the ability of \\ biochar to absorb and retain water. Acacia gerrardii absorbed $403 \%$ and \\ retained $73.6 \%$ water, whereas $T$. aphylla and E. camaldulensis held \\ $396 \%$ and $342 \%$, and then retained $71.5 \%$ and $68.1 \%$ water, respectively. \\ The water holding capacity and water retention ability were lower in \\ biochars pyrolyzed at $300{ }^{\circ} \mathrm{C}$ than $500{ }^{\circ} \mathrm{C}$. The present findings \\ demonstrate that fiber lumen diameter and parenchyma properties provide \\ indicators of biochar hydrological characteristics generated from tree \\ branch wood.
}

Keywords: Wood variation; Feedstock; Branch wood; Biochar hydrological characteristics

Contact information: a: Plant Production Department, College of Food and Agriculture Sciences, King Saud University, P.O. Box 2460, Riyadh 11451, Saudi Arabia; b: Jaga Rimba Nusantara Foundation, Bogor, West Java, Indonesia; *Corresponding author: n.i.suansa@jagarimba.org

\section{INTRODUCTION}

Branch wood is often discarded from commercial enterprises; this forestry byproduct represents a source of abundant lignocellulosic material from natural or plantation forests. Branch wood utilization has gained recent attention due to the decline in main stem wood resources (Leitch and Miller 2017; Zhao et al. 2019). One ecologically friendly method to utilize this source is for generating biochar (Page-Dumroese et al. 2017). Biochar research has advanced precipitously (Verheijen et al. 2014), supporting environmental and sustainable forest management practices (Lehmann 2007; Shrestha et al. 2018; Paz-Ferreiro et al. 2020). Robust conservation management practices have also been developed in critical regions lacking natural resources, particularly in arid and semiarid regions (Andersen and Krzywinski 2007; Li et al. 2018). The benefits of biochar hydrological characteristics should be explored, considering the drought-prone condition in these regions. A recent study predicted temperature increases in arid regions in the ranges of $0.8^{\circ} \mathrm{C}$ to $1.6^{\circ} \mathrm{C}$ and $0.9^{\circ} \mathrm{C}$ to $2.7^{\circ} \mathrm{C}$ by $2025-2044$ and $2045-2064$, respectively (Tarawneh and Chowdhury 2018). High temperature and drought conditions can considerably impact forest health and productivity. Hence, action plans are needed to minimize the effects of climate change. 
Returning biochar to the environment also has some drawbacks. Differences in feedstocks and production temperatures affect the properties of the final product (Jeffery et al. 2011; Calamai et al. 2020). Thus, key parameters that can be used to estimate the characteristics of biochar should be determined. Simple parameters can be beneficial for biochar end-users to predict the suitable applications of biochar products (Aung et al. 2018). Mukome et al. (2013) stated that recognizing the inherent feedstock properties is one of the best approaches for determining the resultant biochar characteristics. Moreover, data on feedstocks properties is readily available. Thus, particular traits of tree species, individual trees, or different parts of trees should be considered when sourcing feedstocks. For example, Moutinho et al. (2016) concluded that different parts of an individual tree generated charcoal with dissimilar physical and mechanical properties due to differences in specific mass and wood moisture content. Pluchon et al. (2014) and Vaughn et al. (2015) also reported the effect of woody properties and tree species on biochar characteristics. However, Pluchon et al. (2014) mixed the branches and stems together for feedstocks, and both studies used only one high production temperature. Mixing feedstocks (Břendová et al. 2012; Yargicoglu et al. 2015; Marmiroli et al. 2018) or comparing biochar originating from different feedstocks (wood, crop residue, poultry manure, solid wastes, etc.) (Lee et al. 2013; Gray et al. 2014; Veiga et al. 2017) are common in biochar studies; however, mixing may alter the feedstock properties. Accordingly, these practices make tracing the origin of biochar characteristics difficult.

Branch wood has unique properties. Mefarrej and Suansa (2019) found that compared with stem and root cells, the length and width of branch wood cells decrease in the acropetal direction. Moreover, branch wood contains a high content of reaction wood (tension wood in angiosperms). Jourez et al. (2001) observed a smaller vessel diameter, lower vessel frequency, and higher number of rays in tension wood than non-tension wood. The current study postulates that the unique properties of branch wood substantially affect the resultant biochar characteristics. Accordingly, species selection based on branch wood basic properties may be a solid approach for producing suitable biochar characteristics for the intended applications (Mukome et al. 2013). In this study, we examined the relationship between tree branch wood's physical, anatomical, and chemical properties and biochar hydrological characteristics. For this purpose, in this work biochar samples with different basic properties were prepared using slow pyrolysis and compared the hydrological characteristics (i.e., water holding capacity, water retention, and hydrophobicity) among them. The biochar hydrological characteristics were quantified and correlated with the physical, anatomical, and chemical properties of the feedstocks. The findings of the present study contribute to the knowledge of how wood types and properties affect biochar characteristics.

\section{EXPERIMENTAL}

\section{Materials}

All samples were collected from the Research Station of Agricultural Experiments, Dirab, Riyadh, Saudi Arabia (24 24' 31.93” N, 046³9' 41.16” E; 584 m above sea level). The area has a continental climate with great seasonal variations in temperature and precipitation (Tarawneh and Chowdhury 2018). The sandy soil $\mathrm{pH}$ is 7.5, indicating slight alkalinity (Mefarrej 2001). Branch wood was collected from the lower third of the tree 
canopy of three tree species: (1) grey-haired acacia (Acacia gerrardii), (2) athel tamarisk (Tamarix aphylla), and (3) red gum (Eucalyptus camaldulensis). Three trees from each species were cut $20 \mathrm{~cm}$ above the basal collar/swelling to avoid irregularity (Zhao et al. 2019). To confirm the specifications of a standard branch, the average branch diameter was determined $6.02 \mathrm{~cm}$, ranging from 5.8 to $6.2 \mathrm{~cm}$. Three branches from each tree were randomly selected to represent the average condition. Wood samples (without bark) were transferred into a water container to retain moisture. An overview of the research methodology is shown in Fig. 1.

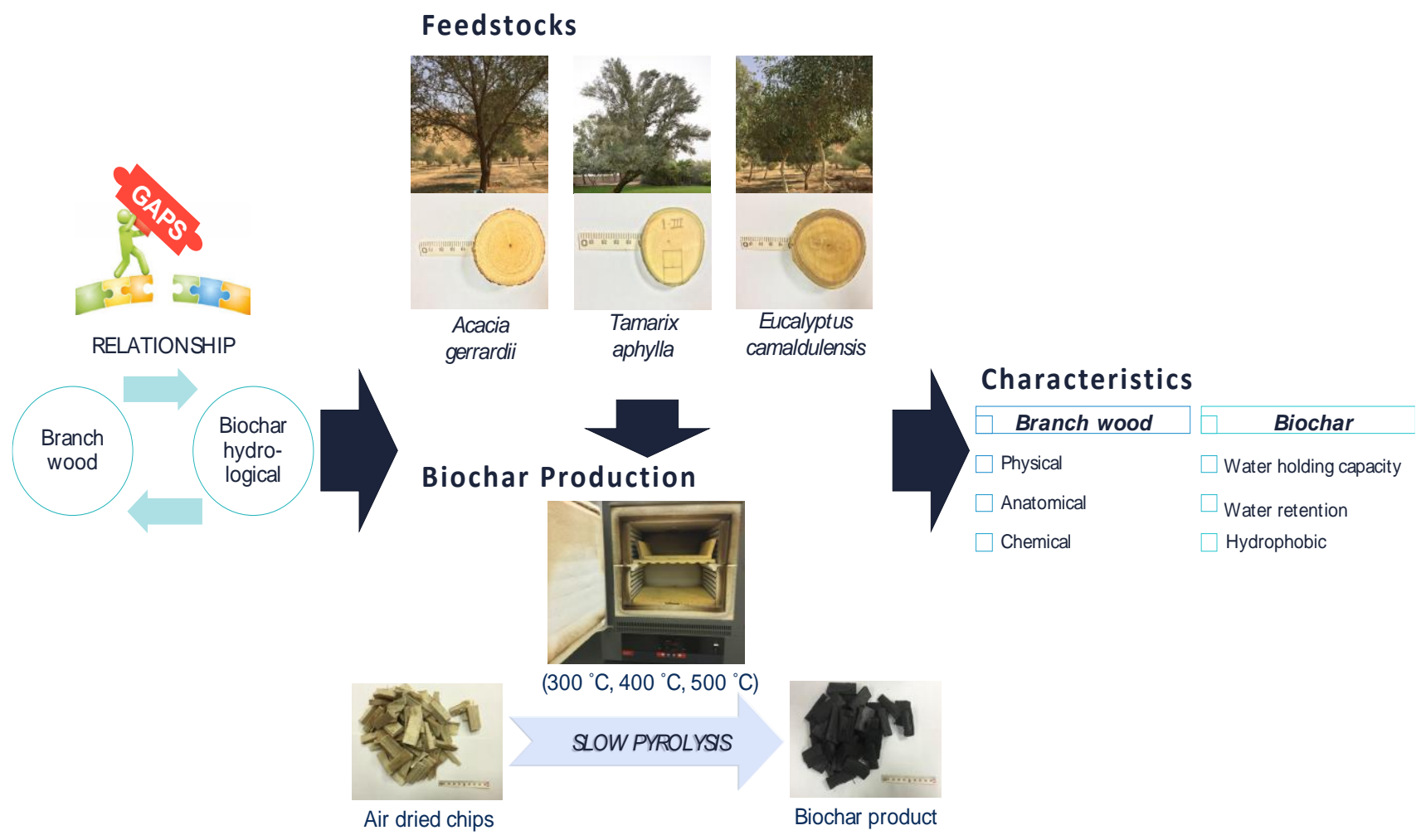

Fig. 1. A brief illustration of research methodology in the present study

\section{Methods}

Experimental design

The factorial experiment was conducted using a completely randomized design. Two factors were included. The first factor was the feedstock source species (A. gerrardii, T. aphylla, and E. camaldulensis), and the second factor was pyrolysis temperature (300 ${ }^{\circ} \mathrm{C}, 400{ }^{\circ} \mathrm{C}$, and $\left.500{ }^{\circ} \mathrm{C}\right)$. Each treatment contained four replicates $(n=3 \times 3 \times 4=36$ samples).

\section{Branch wood basic properties}

Table 1 shows the physical, anatomical, and chemical properties of A. gerrardii, $T$. aphylla, and E. camaldulensis branch wood according to a previous study (Suansa and Mefarrej 2020). 
Table 1. Basic Properties of Acacia gerrardii, Tamarix aphylla, and Eucalyptus camaldulensis Branch Wood

\begin{tabular}{|l|c|c|c|}
\hline \multicolumn{1}{|c|}{ Properties } & A. gerrardii & T. aphylla & E. camaldulensis \\
\hline Physical & & & \\
\hline Specific Gravity & $0.61 \pm 0.01$ & $0.59 \pm 0.03$ & $0.71 \pm 0.01$ \\
\hline Moisture Content $(\%)$ & $90.8 \pm 1.88$ & $100.9 \pm 10.44$ & $60.2 \pm 0.81$ \\
\hline Volumetric Shrinkage (\%) & $22.4 \pm 0.80$ & $32.9 \pm 1.39$ & $15.7 \pm 0.56$ \\
\hline Anatomical & & & \\
\hline Vessel Proportion (\%) & $10.7 \pm 1.05$ & $12.0 \pm 1.50$ & $12.8 \pm 1.32$ \\
\hline Fiber Proportion (\%) & $33.6 \pm 1.64$ & $36.3 \pm 1.91$ & $60.3 \pm 1.48$ \\
\hline Parenchyma Proportion $(\%)$ & $38.0 \pm 1.49$ & $12.8 \pm 1.88$ & $7.9 \pm 0.93$ \\
\hline Rays Proportion $(\%)$ & $17.6 \pm 0.56$ & $38.8 \pm 1.36$ & $18.9 \pm 2.14$ \\
\hline Vessel Diameter $(\mu \mathrm{m})$ & $63.0 \pm 1.41$ & $50.9 \pm 0.76$ & $60.8 \pm 0.97$ \\
\hline Fiber Length $(\mu \mathrm{m})$ & $945.6 \pm 29.71$ & $728.9 \pm 14.09$ & $596.1 \pm 11.50$ \\
\hline Fiber Diameter $(\mu \mathrm{m})$ & $17.1 \pm 0.32$ & $20.9 \pm 0.42$ & $14.0 \pm 0.24$ \\
\hline Lumen Diameter $(\mu \mathrm{m})$ & $7.6 \pm 0.37$ & $12.3 \pm 0.4$ & $4.2 \pm 0.24$ \\
\hline Double-cell Wall Thickness $(\mu \mathrm{m})$ & $9.5 \pm 0.25$ & $8.6 \pm 0.21$ & $9.8 \pm 0.18$ \\
\hline Chemical & & & \\
\hline Extractive $(\%)$ & $6.3 \pm 0.2$ & $8.8 \pm 0.17$ & $4.8 \pm 0.22$ \\
\hline Ash $(\%)$ & $2.9 \pm 0.03$ & $6.3 \pm 0.04$ & $0.9 \pm 0.02$ \\
\hline Cellulose $(\%)$ & $32.2 \pm 0.54$ & $34.1 \pm 1.21$ & $31.1 \pm 0.42$ \\
\hline Hemicellulose $(\%)$ & $33.5 \pm 1.19$ & $33.2 \pm 1.62$ & $39.1 \pm 1.67$ \\
\hline Lignin $(\%)$ & $25.0 \pm 1.85$ & $17.7 \pm 0.49$ & $24.2 \pm 1.67$ \\
\hline
\end{tabular}

\section{Biochar production}

After cleaning with distilled water, branch wood was air-dried for seven days, chopped into chips, and oven-dried overnight at $103{ }^{\circ} \mathrm{C} \pm 2{ }^{\circ} \mathrm{C}$. The wood chips were weighed and tightly packed into an iron box for charring in a muffle furnace. Slow, oxygenlimited pyrolysis was conducted at a rate of $8{ }^{\circ} \mathrm{C}$ to $10{ }^{\circ} \mathrm{C} \mathrm{min}{ }^{-1}$. After reaching the final treatment temperature of $300{ }^{\circ} \mathrm{C}, 400{ }^{\circ} \mathrm{C}$, or $500{ }^{\circ} \mathrm{C}$, the pyrolysis temperature was maintained for approximately $1 \mathrm{~h}$. At the end of the pyrolysis process, the samples were allowed to cool in the muffle furnace overnight before they were moved into the desiccator.

The biochar yield (\%) of each sample ( $n=36$ samples) was calculated according to Lehmann and Joseph (2015) using the following equation (Eq. 1),

$$
Y=\frac{m_{\text {biochar }}}{m_{\text {raw }}}
$$

where $Y$ is yield (\%), mbiochar is the biochar sample mass $(\mathrm{g})$, and $m_{\text {raw }}$ is the raw feedstock mass (g). The $\mathrm{pH}$ and electrical conductivity (EC) of feedstock and biochar were measured by mixing a $1 \mathrm{~g}$ sample with distilled water in a ratio of 1:20 and shaking the mixture for $1.5 \mathrm{~h}$ according to Rajkovich et al. (2012).

\section{Water holding capacity test}

Biochar samples were ground and sieved to obtain fractions less than $3.35 \mathrm{~mm}$ for water holding capacity (WHC) experiments. One gram of each biochar sample was placed in a filtering crucible and placed in a glass beaker with water for $24 \mathrm{~h}$. The crucible was covered with cling-film to prevent evaporation and placed in a container to allow the excess water to drain for $20 \mathrm{~h}$. Wet samples were weighed and then dried in an oven at $105{ }^{\circ} \mathrm{C}$ until reaching a steady weight. The WHC was calculated according to Bikbulatova et al. (2018) using Eq. 2, 


$$
W H C=\frac{M_{2}-M_{3}}{M_{3}-M_{1}} \times 100
$$

where $M_{1}$ is the weight of the glass container $(\mathrm{g}), M_{2}$ is the weight of the wet biochar and glass container $(\mathrm{g})$, and $M_{3}$ is the weight of the oven-dried biochar $(\mathrm{g})$.

\section{Water retention test}

Biochar samples were ground and sieved to obtain 0.125 to $0.5-\mathrm{mm}$ size fractions for water retention (WR) experiments, according to Gray et al. (2014). Ground biochar samples were packed into 3.2-cm tall tubes made from 3-cm PVC pipe, for a total sample volume of $22.61 \mathrm{~cm}^{3}$. Both ends of the pipe were covered with a cloth and fixed with rubber bands. Then the biochar samples were exposed to room temperature for eight days.

On the eighth day, samples were weighed and then submerged in water up to the top of the tube in individual sample cups. Empty tubes served as blanks to determine the amount of water absorbed by the cloth coverings. Samples were drained on wire mesh above the sample cups for $1 \mathrm{~min}$ and then weighed. After each weight measurement, samples were returned to the sample cups, and water was added up to the top of the tube. Core weights were determined hourly for the first $8 \mathrm{~h}$, then daily for $18 \mathrm{~d}$. For each measurement, water content (volume fraction, \%) was calculated by subtracting the biochar weight, sample tube weight and water absorbed in the cloth coverings weight from the total sample weight. The samples were decanted after the last day of measurement, dried at 65 ${ }^{\circ} \mathrm{C}$ for $10 \mathrm{~d}$, and then weighed to measure the dry mass; water density was assumed to be $1 \mathrm{~g} \mathrm{~cm}^{-3}$.

\section{Hydrophobic test}

A water drop penetration time (WDPT) test was conducted to evaluate the degree of hydrophobicity (HP), according to Aller (2017). A 50-mL container was filled with solid biochar, then placed in a weighing boat in an oven at $50{ }^{\circ} \mathrm{C}$ for two weeks. The samples were removed from the oven, and the biochar surface was leveled. Using a plastic transfer pipette, three drops of distilled water were placed on the surface. A stopwatch was used to record the WDPT (in seconds), which was measured as the time elapsed between a single water droplet first touching the biochar surface until it was fully absorbed.

\section{Statistical analysis}

All data were subjected to two-way analysis of variance using Statistical Analysis System (SAS) software (SAS, ver. 9.2, SAS Institute Inc. Cary, NC, USA). The least significant difference test at $p<0.05$ was used to detect differences among the means. Correlations among variables were determined, particularly for branch wood properties and biochar hydrological characteristics.

\section{RESULTS AND DISCUSSION}

\section{Produced Biochar Characteristics}

The feedstocks produced biochar yields of $34 \%$ to $37 \%$ (Table 2). Increasing the pyrolysis temperature from 300 to $500{ }^{\circ} \mathrm{C}$ resulted in a reduction in biochar yield from $41 \%$ to $30.7 \%$. Moreover, results showed that $59 \%$ of the initial wood mass was lost at $300{ }^{\circ} \mathrm{C}$ and another $10.3 \%$ was lost at $500{ }^{\circ} \mathrm{C}$. Tamarix aphylla produced a higher yield, lower $\mathrm{pH}$, 
and higher electrical conductivity (EC) than A. gerrardii and E. camaldulensis at all pyrolysis temperatures.

Table 2. Basic Characteristics of Biochar Produced from Acacia gerrardii, Tamarix aphylla, and Eucalyptus camaldulensis Branch Wood

\begin{tabular}{|l|l|c|c|c|}
\hline \multicolumn{1}{|c|}{ Species } & Temperature & $\mathbf{Y}(\%)$ & $\mathbf{p H}$ & $\mathbf{E C}(\boldsymbol{\mu S} / \mathbf{c m})$ \\
\hline \multirow{4}{*}{ A. gerrardii } & Feedstock & - & $5.34 \pm 0.02$ & $1,155 \pm 27.22$ \\
\cline { 2 - 5 } & $300^{\circ} \mathrm{C}$ & $41.9 \pm 0.82$ & $9.33 \pm 0.04$ & $326.8 \pm 2.82$ \\
\cline { 2 - 5 } & $400^{\circ} \mathrm{C}$ & $34.1 \pm 0.89$ & $9.62 \pm 0.02$ & $474.8 \pm 2.99$ \\
\cline { 2 - 5 } & $500^{\circ} \mathrm{C}$ & $29.7 \pm 0.45$ & $9.82 \pm 0.01$ & $943.2 \pm 2.99$ \\
\hline \multirow{4}{*}{. aphylla } & Feedstock & - & $5.35 \pm 0.03$ & $3,610 \pm 55.08$ \\
\cline { 2 - 5 } & $300^{\circ} \mathrm{C}$ & $43.1 \pm 1.11$ & $7.64 \pm 0.05$ & $1,354.8 \pm 15.58$ \\
\cline { 2 - 5 } & $400^{\circ} \mathrm{C}$ & $37.7 \pm 1.06$ & $8.16 \pm 0.04$ & $1,801.0 \pm 26.37$ \\
\cline { 2 - 5 } & $500^{\circ} \mathrm{C}$ & $33.0 \pm 0.31$ & $9.68 \pm 0.09$ & $2,312.4 \pm 19.99$ \\
\hline \multirow{4}{*}{ camaldulensis } & Feedstock & - & $5.93 \pm 0.01$ & $477 \pm 24.85$ \\
\cline { 2 - 5 } & $300^{\circ} \mathrm{C}$ & $37.9 \pm 1.74$ & $7.60 \pm 0.05$ & $258.9 \pm 4.09$ \\
\cline { 2 - 5 } & $400^{\circ} \mathrm{C}$ & $33.7 \pm 0.56$ & $8.90 \pm 0.04$ & $282.7 \pm 4.01$ \\
\cline { 2 - 5 } & $500^{\circ} \mathrm{C}$ & $29.4 \pm 0.53$ & $9.54 \pm 0.04$ & $406.2 \pm 2.24$ \\
\hline
\end{tabular}

$\mathrm{Y}$, yield; EC, electrical conductivity

Ahmad et al. (2014) reported that slow and moderate pyrolysis processes with a retention time ranging from a few minutes to hours or days generated biochar yields up to $35 \%$, and yields decreased with increasing pyrolysis temperature. By increasing the temperature from $300{ }^{\circ} \mathrm{C}$ to $500{ }^{\circ} \mathrm{C}$, biochar yield decreased from $41 \%$ to $31 \%$. This finding is consistent with Zhao et al. (2017), who reported that the biochar yield of pyrolyzed apple tree branches decreased from $48 \%$ to $32 \%$ when the temperature was increased from 300 ${ }^{\circ} \mathrm{C}$ to $500{ }^{\circ} \mathrm{C}$. Biochar $\mathrm{pH}$ was higher than 7 , regardless of feedstock and temperature. However, increasing the pyrolysis temperature resulted in dramatically more alkaline biochar. This finding may be attributed to the enrichment of basic cations in the ashes with increased temperature, which may be associated with carbonates, oxides, and hydroxides (Yuan et al. 2011) and a decrease in the concentration of acidic surface functional groups (Gezahegn et al. 2019). Several studies found that the $\mathrm{pH}$ of biochar is related to the ash content, which increased at higher pyrolysis temperatures (Lehmann 2007; Chemerys and Baltrènaitè 2018; Weber and Quicker 2018).

\section{Water Holding Capacity}

At $500{ }^{\circ} \mathrm{C}$, A. gerrardii had the highest WHC of $403 \%$, followed by T. aphylla and E. camaldulensis at $396 \%$ and $342 \%$, respectively (Fig. 2). Significant differences between species and pyrolysis temperatures were detected $(p<0.05)$. The average WHC of $A$. gerrardii, T. aphylla, and E. camaldulensis was $394 \%, 370 \%$, and $314 \%$, respectively. The average $\mathrm{WHC}$ was $337 \%$ at $300{ }^{\circ} \mathrm{C}, 361 \%$ at $400{ }^{\circ} \mathrm{C}$, and $380 \%$ at $500{ }^{\circ} \mathrm{C}$. Furthermore, several properties that indirectly reflect the non-lumen fraction were negatively correlated with WHC, including specific gravity (SG; $r=-0.78, p<0.01$ ) and fiber proportion (FP; $r$ $=-0.77, p<0.01)$. Some properties that indirectly reflect the lumen fraction were positively correlated with WHC, including moisture content (MC; $r=0.74, p<0.01$ ), fiber diameter (FD; $r=0.70, p<0.01$ ), lumen diameter (LD; $r=0.66, p<0.05)$, and fiber length (FL; $r$ $=0.64, p<0.05)($ Tables 3 and 4$)$. 


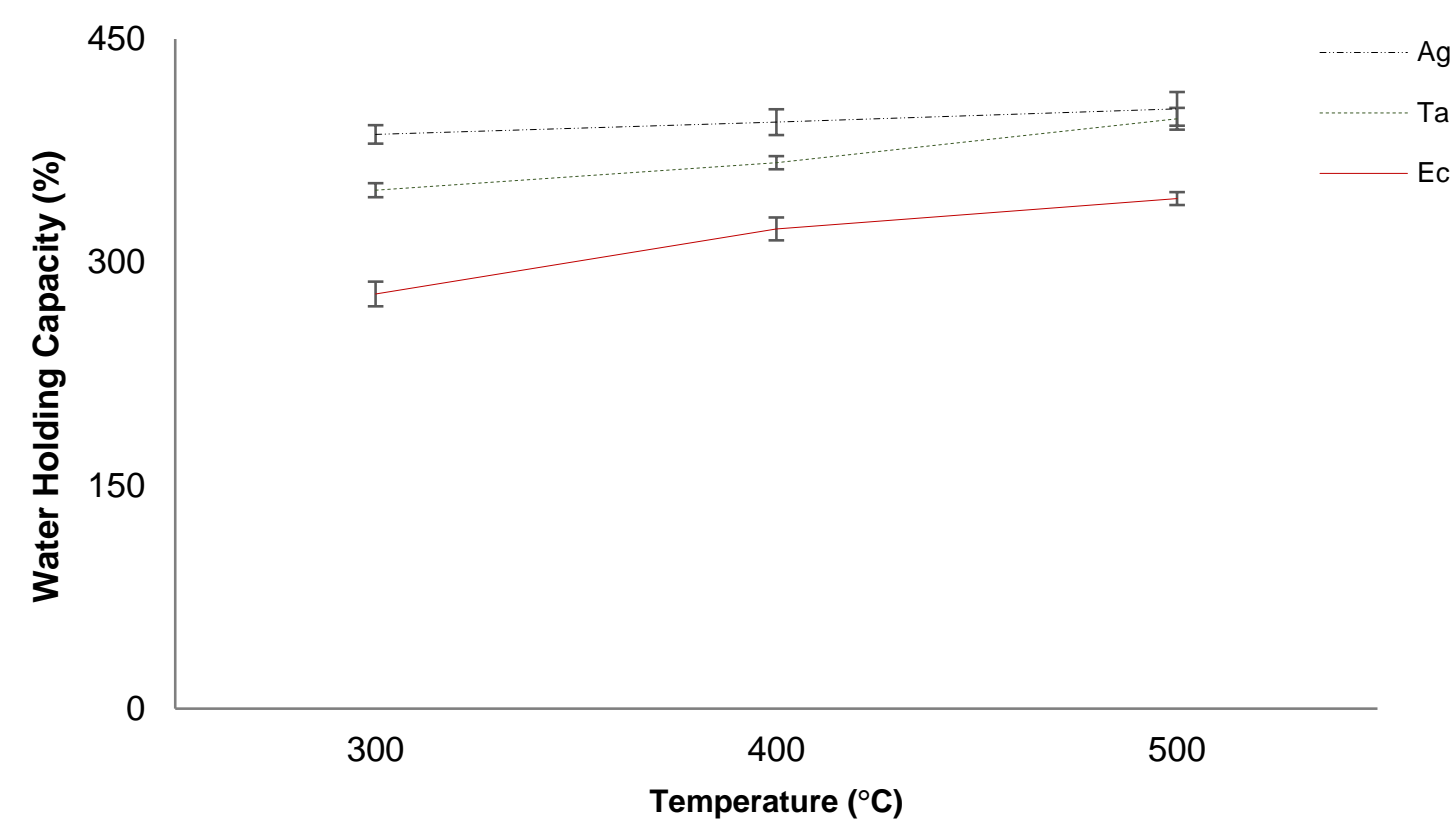

Fig. 2. Water holding capacity of Acacia gerrardii (Ag), Tamarix aphylla (Ta), and Eucalyptus camaldulensis $(\mathrm{Ec})$. Points represent the mean of measurements and error bars show standard error.

In this study, the correlations between physical (Table 3) and anatomical (Table 4) branch wood properties with biochar hydrological characteristics were more pronounced than those with branch wood chemical properties (Table 5). The highest biochar WHC was produced from $A$. gerrardii, representing the correlation between WHC and basic properties of $A$. gerrardii, particularly fiber properties that reflect the lumen fraction (Table 4). Thus, the fiber anatomical properties and derived physical properties (Table 3) were good indicators of biochar hydrological characteristics. These porous structures generate a large portion of the residual porosity (Gray et al. 2014). Correspondingly, the higher lignin content of $A$. gerrardii may result in extra porosity in the biochar structure (Chemerys and Baltrènaitè-Gedienè 2018). These data confirm that assessing the feedstock anatomical features provides a simple method for estimating the ability of biochar to retain water. Baltrènaitè-Gedienè et al. (2016) found that biochar hydrological characteristics are related to the biochar structure, particularly residual porosity, which is affected by the the slight changes in wood macrostructure during thermal decomposition (Weber and Quicker 2018). In addition, wood-derived biochar likely preserves the initial wood pore structure (Baltrènaitè-Gedienè et al. 2016).

The WHC increased with an increase in pyrolysis temperature. The porosity, pore surface area, and pore volume were lowest when wood was pyrolyzed at $300{ }^{\circ} \mathrm{C}$. Pore properties increase with increasing temperature up to $750{ }^{\circ} \mathrm{C}$ (Baltrènaitè-Gedienè et al. 2016). A model proposed by Young-Laplace may explain the relationship (Hyväluoma et al. 2018); increasing temperature alters the hydrological characteristics by changing the surface wettability (contact angle) (Suliman et al. 2017) or pore size distribution (pore diameter) (Pulido-Novicio et al. 2001). Moreover, wettability increases with a decrease in contact angle or increase in pore volume (Hyväluoma et al. 2018). 
Table 3. Correlation between Branch Wood Physical Properties and Biochar Hydrological Characteristics

\begin{tabular}{|l|l|l|l|}
\hline Properties & Specific Gravity & Moisture Content & Volumetric Shrinkage \\
\hline Water Holding Capacity & $-0.78^{\star *}$ & $0.74^{\star *}$ & $0.72^{\star *}$ \\
\hline Water Retention & $-0.79^{\star *}$ & $0.88^{\star *}$ & $0.84^{\star *}$ \\
\hline Hydrophobicity & $-0.64^{\star}$ & 0.53 & 0.33 \\
\hline
\end{tabular}

${ }^{\star} p<0.05,{ }^{* *} p<0.01$

Table 4. Correlation between Branch Wood Anatomical Properties and Biochar Hydrological Characteristics

\begin{tabular}{|l|l|l|l|l|l|l|l|l|l|}
\hline Properties & FL & FD & LD & DCWT & VD & VP & FP & PP & RP \\
\hline $\begin{array}{l}\text { Water Holding } \\
\text { Capacity }\end{array}$ & $0.64^{*}$ & $0.70^{* *}$ & $0.66^{*}$ & -0.29 & -0.28 & -0.24 & $-0.77^{* *}$ & 0.41 & 0.42 \\
\hline $\begin{array}{l}\text { Water } \\
\text { Retention }\end{array}$ & 0.31 & $0.83^{\star *}$ & $0.81^{* *}$ & -0.5 & $-0.56^{*}$ & -0.1 & $-0.70^{* *}$ & 0.09 & $0.76^{\star *}$ \\
\hline Hydrophobicity & $0.85^{\star *}$ & 0.35 & 0.34 & -0.19 & 0.15 & -0.36 & $-0.82^{* *}$ & $0.84^{\star *}$ & -0.08 \\
\hline
\end{tabular}

FL, Fiber Length; FD, Fiber Diameter; LD, Lumen Diameter; DCWT, Double-cell Wall Thickness; VD, Vessel Diameter; VP, Vessel Proportion; FP, Fiber Proportion; PP, Parenchyma Proportion; RP, Rays Proportion $\left({ }^{*} p<0.05,{ }^{* *} p<0.01\right)$

Table 5. Correlation between Branch Wood Chemical Properties and Biochar Hydrological Characteristics

\begin{tabular}{|l|l|l|l|l|l|}
\hline Properties & Extractive & Ash & Cellulose & Hemicellulose & Lignin \\
\hline Water Holding Capacity & -0.22 & -0.26 & -0.04 & 0.44 & -0.16 \\
\hline Water Retention & 0.04 & 0.06 & -0.12 & 0.39 & -0.37 \\
\hline Hydrophobicity & 0.17 & 0.04 & 0.49 & 0.24 & -0.52 \\
\hline
\end{tabular}

\section{Water Retention}

Figure 3 shows that biochar generated from A. gerrardii retained the most water. Water retention ability was significantly lower at lower pyrolysis temperatures $(p<0.05)$. The WR of A. gerrardii was 73.6\%, followed by T. aphylla and E. camaldulensis at $71.5 \%$ and $68.1 \%$, respectively. Biochar that was produced at $300{ }^{\circ} \mathrm{C}, 400{ }^{\circ} \mathrm{C}$, and $500{ }^{\circ} \mathrm{C}$ retained $68.9 \%, 72.4 \%$, and $71.8 \%$ water, respectively. Some properties that indirectly reflect the non-lumen fraction were negatively correlated with WR, such as SG $(r=-0.79, p<0.01)$ and FP $(r=-0.70, p<0.01)$, whereas several properties that indirectly reflect the lumen fraction were positively correlated with $\mathrm{WR}$, including $\mathrm{MC}(r=0.88, p<0.01)$, FD $(r=$ $0.83, p<0.01), \mathrm{LD}(r=0.81, p<0.01)$, and ray proportion (RP; $r=0.76, p<0.01)$ (Tables 3 and 4$)$.

Similar to WHC, the highest WR was observed in A. gerrardii biochar, and higher pyrolysis temperature resulted in increased WR values. The trends that determine WHC and WR are affected by identical factors, namely, biochar porosity (Bikbulatova et al. 2018) and functional groups (Kinney et al. 2012; Weber and Quicker 2018). Functional groups decrease and porosity increases at higher pyrolysis temperatures (Weber and Quicker 2018). Additionally, the present study found that slight changes in WR value might occur as a result of mechanical force when preparing the samples. Generally, the WR curve plateaued after the eighth day of measurement, which may occur when the residual 
macropores, external pores, and small pyrogenic nanopores are filled with water. However, another study reported that steady WR existed even though after seven days of observation (Gray et al. 2014). Moreover, it is important to note that the biochar produced from $A$. gerrardii at $300{ }^{\circ} \mathrm{C}$ had the lowest WR value from the initial measurement up to several hours of observation, but it surpassed biochar generated from the other two species on the next observation day. This phenomenon might be connected to the degree of hydrophobicity and the tendency of hydrophobic substances (such as wood extractives) to rise to the surface of woody materials upon heating, clogging pores (Kinney et al. 2012; Gray et al. 2014). Das and Sarmah (2015) also reported that biochar produced at lower pyrolysis temperatures exhibited pore clogging via tars, which reduced the number of pores and surface area.

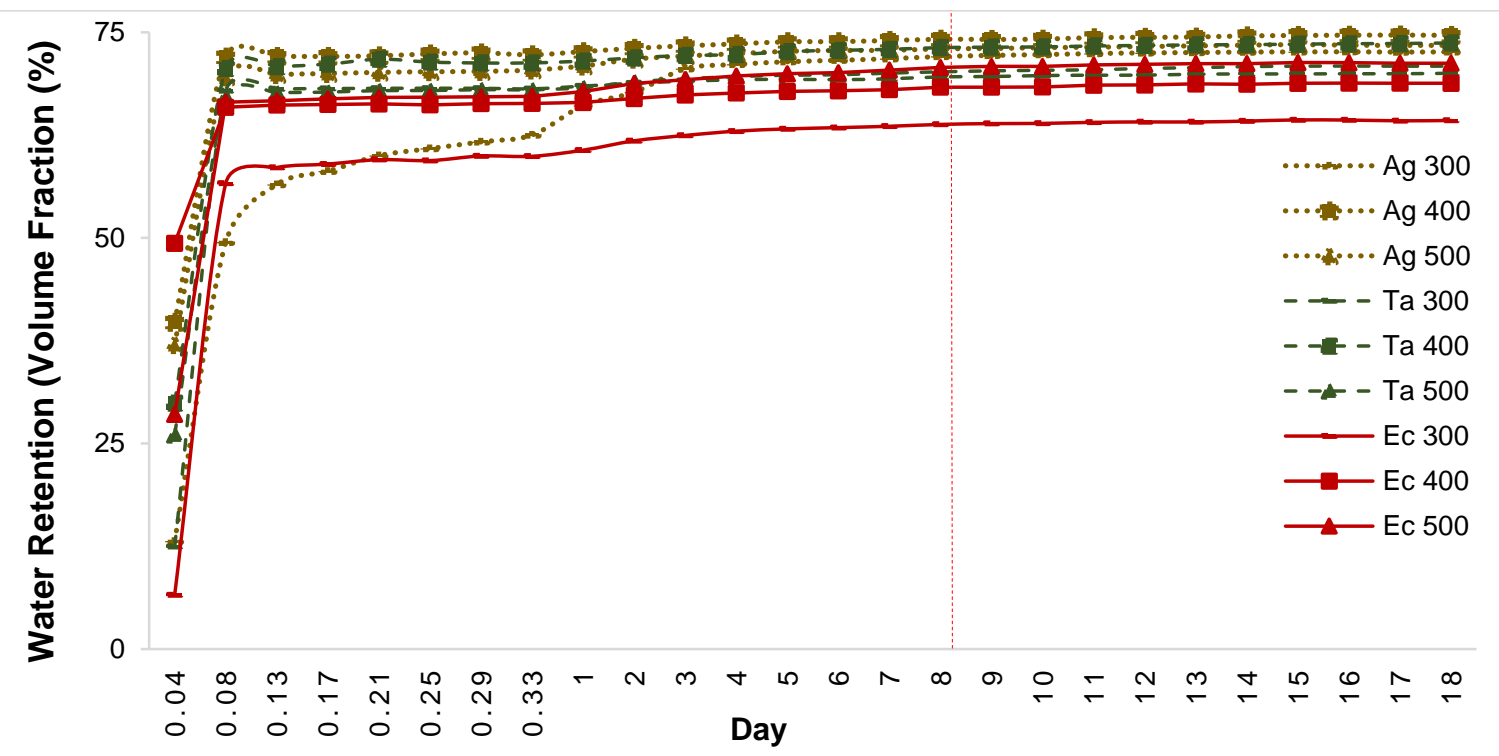

Fig. 3. Water uptake of Acacia gerrardii (Ag), Tamarix aphylla (Ta), and Eucalyptus camaldulensis $(\mathrm{Ec})$ biochar produced at $300^{\circ} \mathrm{C}, 400{ }^{\circ} \mathrm{C}$, and $500{ }^{\circ} \mathrm{C}$. The red line indicates the plateau point, after which constant values were observed.

\section{Degree of Hydrophobicity}

Figure 4 shows that the longest water droplet penetration time was observed in biochar produced from A. gerrardii (3,741.4 s), followed by E. camaldulensis (897.5 s), and $T$. aphylla $(95.5 \mathrm{~s})$. The longest penetration times occurred in biochar pyrolyzed at 300 ${ }^{\circ} \mathrm{C}(p<0.05)$. The penetration time decreased with increasing pyrolysis temperatures, that generated from A. gerrardii. However, no significant differences were observed between biochars produced at $400{ }^{\circ} \mathrm{C}$ and $500{ }^{\circ} \mathrm{C}$. Biochar degree of hydrophobicity (HP) was classified from slightly to extremely hydrophobic. Some properties that indirectly reflect the non-lumen fraction were negatively correlated with HP, including FP $(r=-0.82, p<$ $0.01)$ and SG $(r=-0.64, p<0.05)$; some properties that indirectly reflect the lumen fraction were positively correlated with HP, such as FL $(r=0.85, p<0.01)$ and parenchyma proportion (PP; $r=0.84, p<0.01$ ) (Tables 3 and 4).

Hydrophobicity is a result of aliphatic surface functional groups (Kinney et al. 2012; Aller 2017; Weber and Quicker 2018). The highest degree of hydrophobicity (extremely hydrophobic) was observed in A. gerrardii biochar, especially that pyrolyzed 
at the lowest temperature, followed by E. camaldulensis and T. aphylla. The extreme hydrophobicity of $A$. gerrardii biochar products may derive from the organic functional groups content (Kinney et al. 2012; Gray et al. 2014), carbonates (such as $\mathrm{CaCO}_{3}$ and $\mathrm{MgCO}_{3}$ ), or inorganic alkalis (such as $\mathrm{Na}$ and K) (Yuan et al. 2011; Fidel 2012; Lee et al. 2013). Some organic functional groups can partially increase biochar $\mathrm{pH}$ by neutralizing acidic substances (Bai et al. 2017). Generally, high organic functional group content in biochar products is controlled by the high percentage of aromatic carbons particularly fused-ring aromatic structures and aromatic $\mathrm{C}-\mathrm{O}$ groups ( $\mathrm{Li}$ et al. 2013). Although the organic functional groups were not analyzed in the present study, the extreme hydrophobicity of $A$. gerrardii may result from its high $\mathrm{pH}$ value, which was higher than those of E. camaldulensis and T. aphylla (Table 2).

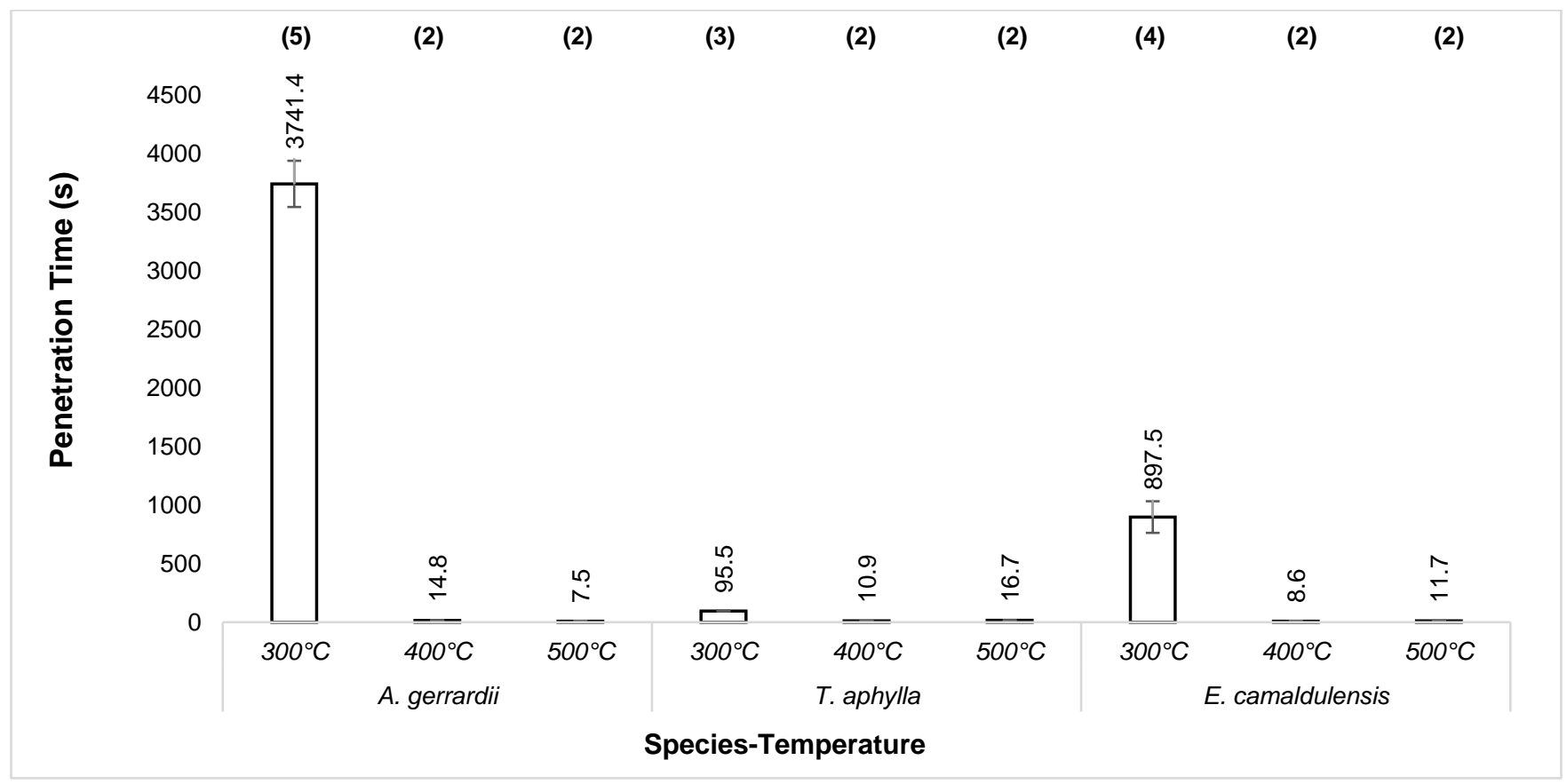

Fig. 4. Water droplet penetration time of Acacia gerrardii, Tamarix aphylla, and Eucalyptus camaldulensis biochar produced at $300^{\circ} \mathrm{C}, 400^{\circ} \mathrm{C}$, and $500^{\circ} \mathrm{C}$. The degree of biochar hydrophobicity according to Aller (2017) is indicated within parentheses.

Moreover, in biochar pyrolyzed at the low temperature, the pore structure is not easily accessible due to smaller pore size, less interconnection among pores, and remaining tars and oils compounds that clog pores (Gray et al. 2014; Das and Sarmah 2015). The temperature of $300{ }^{\circ} \mathrm{C}$ was not adequate to break down the organic functional groups. The degree of hydrophobicity in this study markedly decreased by increasing pyrolysis temperature. Functional groups are volatilized at higher temperatures (Kinney et al. 2012), which may increase hydrological ability by reducing the degree of hydrophobicity (Gray et al. 2014; Weber and Quicker 2018). Two main processes influence this property, namely, the alteration of material affinity and water adsorption because of the decrease in organic functional groups and increase in porosity (Weber and Quicker 2018). 


\section{CONCLUSIONS}

1. Acacia gerrardii biochar exhibited a higher ability to absorb and retain water than $T$. aphylla and E. camaldulensis biochar due to its more porous structure.

2. The feedstock anatomical features (mainly fiber lumen diameter and parenchyma properties of lignocellulosic material) provide indicators of biochar hydrological characteristics.

3. The selection of appropriate branch wood feedstocks may become a natural modification to provide suitable biochar products for the intended applications.

4. Further investigations are needed to address how biochar water holding capacity (WHC) compares to that of the feedstock wood, and how the organic functional compounds in biochar relate to branch wood properties.

\section{ACKNOWLEDGMENTS}

The authors thank the Deanship of Scientific Research, King Saud University and the Agricultural Research Center, College of Food and Agricultural Science, for funding this research.

\section{REFERENCES CITED}

Ahmad, M., Rajapaksha, A. U., Lim, J. E., Zhang, M., Bolan, N., Mohan, D., Vithanage, M., Lee, S. S., and Ok, Y. S. (2014). "Biochar as a sorbent for contaminant management in soil and water: a review," Chemosphere 99, 19-33. DOI: 10.1016/j.chemosphere.2013.10.071

Aller, D. M. (2017). Scaling Understanding of Biochar Aging Impacts on Soil Water and Crop Yields, Ph.D. Dissertation, Iowa State University, Ames, IA, USA.

Andersen, G. L., and Krzywinski, K. (2007). "Mortality, recruitment and change of desert tree populations in a hyper-arid environment," PLOS ONE 2(2), 1-10. DOI: 10.1371/journal.pone.0000208

Aung, A., Han, S. H., Youn, W. B., Meng, L., Cho, M. S., and Park, B. B. (2018). "Biochar effects on the seedling quality of Quercus serrata and Prunus sargentii in a containerized production system," Forest Sci Technol. 14(3), 112-118. DOI: 10.1080/21580103.2018.1471011

Bai, X. F., Zhou, X. Q., Li, Z. F., Ni, J. W., and Bai, X. (2017). "Properties and applications of biochars derived from different biomass feedstock sources," Int. J. Agric. \& Biol. Eng. 10(2), 242-250.

Baltrènaite-Gedienė, E., Baltrenas, P., and Lietuvninkas, A. (2016). The Sustainable Role of the Tree in Environmental Protection Technologies, Springer International Publishing, Switzerland, pp. 344.

Bikbulatova, S., Tahmasebi, A., Zhang, Z., Rish, S. K., and Yu, J. (2018). "Understanding water retention behavior and mechanism in bio-char," Fuel Process. Technol. 169, 101-111. DOI: 10.1016/j.fuproc.2017.09.025 
Břendová, K., Tlustoš, P., Száková, J., and Habart, J. (2012). "Biochar properties from different materials of plant origin," Eur. Chem. Bull. 1(12), 535-539. DOI:

10.17628/ecb.2012.1.535-539

Calamai, A., Chiaramonti, D., Casini, D., Masoni, A., and Palchetti, E. (2020). "Shortterm effects of organic amendments on soil properties and maize (Zea maize L.) growth," Agriculture 10(5), 158. DOI: 10.3390/agriculture10050158

Chemerys, V., and Baltrènaitè-Gedienè, E. (2018). "Influence of intrinsic properties of lignocellulosic feedstock on adsorptive properties of biochar," J. Environ. Eng. 144(9), 04018075. DOI: 10.1061/(ASCE)EE.1943-7870.0001420

Das, O., and Sarmah, A. K. (2015). "The love-hate relationship of pyrolysis biochar and water: A perspective," Sci. Total Environ. 512-513, 682-685. DOI:

10.1016/j.scitotenv.2015.01.061

Fidel, R. (2012). Evaluation and Implementation of Methods for Quantifying Organic and Inorganic Components of Biochar Alkalinity, Master's Thesis, Iowa State University, Ames, US.

Gezahegn, S., Sain, M., and Thomas, S. C. (2019). "Variation in feedstock wood chemistry strongly influences biochar liming potential," Soil Syst. 3(2), 26. DOI: 10.3390/soilsystems 3020026

Gray, M., Johnson, M. G., Dragila, M. I., and Kleber, M. (2014). "Water uptake in biochars: The roles of porosity and hydrophobicity," Biomass Bioenerg. 61, 196-205. DOI: 10.1016/j.biombioe.2013.12.010

Hyväluoma, J., Hannula, M., Arstila, K., Wang, H., Kulju, S., and Rasa, K. (2018). "Effects of pyrolysis temperature on the hydrologically relevant porosity of willow biochar," J. Anal. Appl. Pyrolysis 134, 446-453. DOI: 10.1016/j.jaap.2018.07.011

Jeffery, S., Verheijen, F. G. A., Velde, M. van der, and Bastos, A. C. (2011). “A quantitative review of the effects of biochar application to soils on crop productivity using meta-analysis," Agric. Ecosyst. Environ. 144(1), 175-187. DOI: 10.1016/j.agee.2011.08.015

Jourez, B., Riboux, A., and Leclercq, A. (2001). "Anatomical characteristics of tension wood and opposite wood in young inclined stems of poplar (Populus euramericana Cv 'Ghoy')," Iawa Journal. 22(2), 133-157. DOI:10.1163/22941932-90000274

Kinney, T. J., Masiello, C. A., Dugan, B., Hockaday, W. C., Dean, M. R., Zygourakis, K., and Barnes, R. T. (2012). "Hydrologic properties of biochars produced at different temperatures," Biomass Bioenerg. 41, 34-43. DOI: 10.1016/j.biombioe.2012.01.033

Lee, Y., Park, J., Ryu, C., Gang, K. S., Yang, W., Park, Y.-K., Jung, J., and Hyun, S. (2013). "Comparison of biochar properties from biomass residues produced by slow pyrolysis at $500{ }^{\circ} \mathrm{C}$," Bioresource Technol. 148, 196-201. DOI: 10.1016/j.biortech.2013.08.135

Lehmann, J. (2007). “A handful of carbon,” Nature 447(7141), 143-144. DOI: $10.1038 / 447143 a$

Lehmann, J., and Joseph, S. (2015). Biochar for Environmental Management: Science and Technology, Routledge, London, UK, pp. 976.

Leitch, M., and Miller, S. (2017). "Optimizing wood utilization based on whole tree inherent property maps," in: Wood is Good: Current Trends and Future Prospects in Wood Utilization, Springer, Singapore, pp. 3-17.

Li, Q., Jia, Z., Feng, L., He, L., and Yang, K. (2018). "Dynamics of biomass and carbon sequestration across a chronosequence of Caragana intermedia plantations on alpine 
sandy land," Sci. Rep. 8(1), 12432. DOI: 10.1038/s41598-018-30595-3

Li, X., Shen, Q., Zhang, D., Mei, X., Ran, W., Xu, Y., and Yu, G. (2013). "Functional groups determine biochar properties ( $\mathrm{pH}$ and $\mathrm{EC}$ ) as studied by two-dimensional 13C NMR correlation spectroscopy," PLOS ONE 8(6), e65949. DOI: 10.1371/journal.pone.0065949

Marmiroli, M., Bonas, U., Imperiale, D., Lencioni, G., Mussi, F., Marmiroli, N., and Maestri, E. (2018). "Structural and functional features of chars from different biomasses as potential plant amendments," Front. Plant Sci. 9, 1119. DOI: 10.3389/fpls.2018.01119

Mefarrej, H. A. A. (2001). The Natural Durability against Fungal Decay of Some Hardwoods Grown in Saudi Arabia and Its Relationship with Basic Wood Properties, $\mathrm{Ph}$. D. Dissertation, Imperial College of Science, London, UK.

Mefarrej, H. A. A., and Suansa, N. I. (2019). "Trait-based ecology using conduits comparison approach," Wood Res. 64(6), 1055-1064.

Moutinho, V. H. P., Filho, M. T., Brito, J. O., Ballari, A. W., and Andrade, F. W. C. (2016). "Influence of the wood physical properties on the charcoal physical and mechanical properties," Sci. For. 44(111), 557-561. DOI:

$10.18671 /$ scifor.v44n111.02

Mukome, F. N. D., Zhang, X., Silva, L. C. R., Six, J., and Parikh, S. J. (2013). "Use of chemical and physical characteristics to investigate trends in biochar feedstocks," $J$. Agric. Food Chem. 61(9), 2196-2204. DOI: 10.1021/jf3049142

Page-Dumroese, D., Busse, M., Archuleta, J., McAvoy, D., and Roussel, E. (2017). "Methods to reduce forest residue volume after timber harvesting and produce black carbon," Scientifica 2017, 1-8. DOI: 10.1155/2017/2745764

Paz-Ferreiro, J., Méndez, A.-M., Gascó, G., and Figueiredo, C. C. (2020). "Special issue on "environmental applications of biochar," Appl. Sci. 10(17), 6076. DOI: 10.3390/app10176076

Pluchon, N., Gundale, M. J., Nilsson, M.-C., Kardol, P., and Wardle, D. A. (2014). "Stimulation of boreal tree seedling growth by wood-derived charcoal: Effects of charcoal properties, seedling species and soil fertility," Funct. Ecol. 28(3), 766-775. DOI: $10.1111 / 1365-2435.12221$

Pulido-Novicio, L., Hata, T., Kurimoto, Y., Doi, S., Ishihara, S., and Imamura, Y. (2001). "Adsorption capacities and related characteristics of wood charcoals carbonized using a one-step or two-step process," J. Wood Sci. 47(1), 48-57. DOI:

10.1007/BF00776645

Rajkovich, S., Enders, A., Hanley, K., Hyland, C., Zimmerman, A. R., and Lehmann, J. (2012). "Corn growth and nitrogen nutrition after additions of biochars with varying properties to a temperate soil," Biol. Fertil. Soils 48(3), 271-284. DOI:

10.1007/s00374-011-0624-7

Shrestha, B. M., Chang, S. X., Bork, E. W., and Carlyle, C. N. (2018). "Enrichment planting and soil amendments enhance carbon sequestration and reduce greenhouse gas emissions in agroforestry systems: A review," Forests 9(6), 369. DOI: $10.3390 / f 9060369$

Suansa, N. I., and Mefarrej, H. A. A. (2020). "Branch wood properties and potential utilization of this variable resource," BioResources 15(1), 479-491. DOI: 10.15376/biores.15.1.479-491

Suliman, W., Harsh, J. B., Abu-Lail, N. I., Fortuna, A.-M., Dallmeyer, I., and Garcia- 
Pérez, M. (2017). "The role of biochar porosity and surface functionality in augmenting hydrologic properties of a sandy soil," Sci. Total Environ. 574, 139-147. DOI: 10.1016/j.scitotenv.2016.09.025

Tan, Z., Lin, C. S. K., Ji, X., and Rainey, T. J. (2017). "Returning biochar to fields: A review," Appl. Soil Ecol., 116, 1-11. DOI: 10.1016/j.apsoil.2017.03.017

Tarawneh, Y. Q., and Chowdhury, S. (2018). "Trends of climate change in Saudi Arabia: Implications on water resources," Climate 6(1), 8. DOI: 10.3390/cli6010008

Vaughn, S. F., Kenar, J. A., Eller, F. J., Moser, B. R., Jackson, M. A., and Peterson, S. C. (2015). "Physical and chemical characterization of biochars produced from coppiced wood of thirteen tree species for use in horticultural substrates," Ind. Crops Prod. 66, 44-51. DOI: 10.1016/j.indcrop.2014.12.026

Veiga, T. R. L. A., Lima, J. T., Dessimoni, A. L. de A., Pego, M. F. F., Soares, J. R., and Trugilho, P. F. (2017). "Different plant biomass characterizations for biochar production," Cerne 23, 529-536. DOI: 10.1590/01047760201723042373

Verheijen, F. G. A., Graber, E. R., Ameloot, N., Bastos, A. C., Sohi, S., and Knicker, H. (2014). "Biochars in soils: New insights and emerging research needs," Eur. J. Soil Sci. 65(1), 22-27. DOI: 10.1111/ejss.12127

Weber, K., and Quicker, P. (2018). "Properties of biochar," Fuel 217, 240-261. DOI: 10.1016/j.fuel.2017.12.054

Yargicoglu, E. N., Sadasivam, B. Y., Reddy, K. R., and Spokas, K. (2015). "Physical and chemical characterization of waste wood derived biochars," Waste Manag. 36, 256268. DOI: 10.1016/j.wasman.2014.10.029

Yuan, J.-H., Xu, R.-K., and Zhang, H. (2011). "The forms of alkalis in the biochar produced from crop residues at different temperatures," Bioresour. Technol. 102(3), 3488-3497. DOI: 10.1016/j.biortech.2010.11.018

Zhao, S.-X., Ta, N., and Wang, X.-D. (2017). "Effect of temperature on the structural and physicochemical properties of biochar with apple tree branches as feedstock material," Energies 10, 1293. DOI: 10.3390/en10091293

Zhao, X., Guo, P., Zhang, Z., and Peng, H. (2019). “Anatomical features of branchwood and stemwood of Betula costata Trautv. from natural secondary forests in China," BioResources 14(1), 1980-1991. DOI: 10.15376/biores.14.1.1980-1991

Article submitted: November 14, 2020; Peer review completed: December 27, 2020; Revised version received: February 17, 2021; Accepted: February 22, 2021; Published: February 25, 2021.

DOI: 10.15376/biores.16.2.2824-2837 